\section{FRI0190 RELATIONSHIP BETWEEN FAECAL CALPROTECTIN, HLAB-27 AND ACUTE PHASE REACTANTS IN PATIENTS WITH SPONDYLOARTHRITIS WITHOUT PRIOR DIAGNOSIS OF INFLAMMATORY BOWEL DISEASE}

C. Ramos Giraldez ${ }^{1}$, M. Espinosa Malpartida ${ }^{1}$, C. Merino Argumánez ${ }^{1}$, B. Ruíz Antorán ${ }^{2}$, J. Campos Esteban ${ }^{1}$, C. Barbadillo Mateos ${ }^{1}$, H. Godoy Tundidor ${ }^{1}$, B. Agudo Castillo ${ }^{3}$, Y. González Lama ${ }^{3}$, J.L. Andréu Sánchez ${ }^{1}$, J. Sanz Sanz ${ }^{1}$. ${ }^{1}$ Rheumatology Service; ${ }^{2}$ Clinical Pharmacology Service; ${ }^{3}$ Gastroenterology Service, Hospital Universitario Puerta De Hierro Majadahonda, Madrid, Spain

Background: Faecal calprotectin (FC) is a biomarker of inflammatory bowel activity widely used in the diagnosis and follow-up of inflammatory bowel disease (IBD). Microscopic intestinal inflammation is described in approximately $50 \%$ of patients with spondyloarthritis $(\mathrm{SpA})$, and it is associated with more severe disease.

Objectives: The purpose of this study was to describe the possible relationship between FC, HLAB27 and acute phase reactants in patients diagnosed of SpA without clinical suspicion or prior diagnosis of IBD.

Methods: Unicentric, cross-sectional observational study with prospective clinical data collection. We included consecutively selected patients in the Rheumatology Clinic diagnosed of SpA who fulfilled ASAS criteria and did not have digestive symptoms suggestive of IBD (chronic diarrhoea, rectal bleeding, perianal disease or chronic abdominal pain persistent/recurrent). Demographic, clinical and analytical data from SpA (Uveitis, HLAB27, acute phase reactants), treatments and FC were collected and a FC cut-off point $>50 \mathrm{MG} / \mathrm{kg}$ was determined. For patients on NSAIDS suspension was recommended two weeks prior to collection of stool samples. The study was approved by the centre's Ethics Committee for Clinical Trials.

Results: Ninety-nine patients were included. 50\% male, average age $46 \pm 11$ years old. $3.7 \pm 2.5$ BASDAI. 79\% HLA-B27 positive, 31\% had elevated levels of ESR, $9 \%$ elevated CRP (>10 mg/L). 49 patients $(49.5 \%$ ) had high levels of FC, with mean levels of $276 \mathrm{mg} / \mathrm{Kg}$ (range 52-3,038). HLAB27 positive patients had significantly higher FC levels than HLAB27 negative patients $(160 \mathrm{mg} / \mathrm{kg}$ vs $98 \mathrm{mg} / \mathrm{kg} ; \mathrm{p}<0.05)$. There were no differences in relation to the history of uveitis. Patients with high FC had significantly higher CRP levels than patients with normal FC (6.7 mg/L vs. $3.2 \mathrm{mg} / \mathrm{L} ; p<0.05)$, in accordance with these results from the group of patients with CRP levels $>10 \mathrm{mg} / \mathrm{L}$, the percentage of $\mathrm{FC}$ elevation was $78 \%$ vs. $47 \%$ of patients with CRP $<10 \mathrm{mg} / \mathrm{L}$. There were no significant differences in relation to ESR.

Conclusions: Patients with spondyloarthritis (ASAS criteria), HLAB27 positive and elevated CRP have higher levels of faecal calprotectin, a biomarker of inflammatory bowel activity, which may indicate that inflammatory activity in SpA might be associated with subclinical intestinal inflammation.

Disclosure of Interest: None declared

DOI: 10.1136/annrheumdis-2018-eular.5902

\section{FRI0191 SIMILARITIES AND DIFFERENCES BETWEEN OSTEITIS CONDENSANS ILII AND AXIAL SPONDYLOARTHRITIS PATIENTS PRESENTING WITH CHRONIC BACK PAIN IN A RHEUMATOLOGY SETTING}

D. Poddubnyy ${ }^{1,2}$, H. Weineck ${ }^{1}$, J. Listing ${ }^{2}$, T. Diekhoff ${ }^{1}$, K.-G. Hermann ${ }^{1}$ J. Sieper ${ }^{1} .{ }^{1}$ Charité UniversitäTsmedizin Berlin; ${ }^{2}$ German Rheumatism Research Centre, Berlin, Berlin, Germany

Background: Osteitis condensans ilii $(\mathrm{OCl})$ is regarded as a non-inflammatory disorder, which is considered to be induced by mechanical stress (e.g., by pregnancy and delivery). The diagnosis is normally based on wide spread sclerosis of the sacroiliac joint without erosions or ankyloses on imaging. More recently, paraarticular bone marrow oedema has been described on MRI, which can occur early but also intermittently later in the course of the disease. The clinical characteristics of OCl patienst have not been well described. To date, there are no published systematic data on the characteristics of $\mathrm{OCl}$ as compared to axial spondyloarthritis (axSpA).

Objectives: The objective of this matched case-control study was to investigate demographic, clinical, and lab characteristics of $\mathrm{OCl}$ as compared to axSpA.

Methods: Using medical database search we have identified $n=103$ patients aged $\geq 18$ years who were diagnosed with $\mathrm{OCl}$ upon presentation with chronic back pain in the Early Spondyloarthritis Clinic of the rheumatology department in the Charité University Hospital between January 2010 and May 2015. These patients were contacted in order to obtain an informed consent and to complete a survey on the disease-related history. $\mathrm{n}=60 \mathrm{OCl}$ patients who provided an informed consent and completed the survey were included in the final analysis. These patients were matched with a 1:2 ratio according to the back pain duration to patients with definite axSpA diagnosed in the same setting in order to compare demographic, clinical and lab characteristics.
Abstract FRI0191 - Table 1. Demographic, clinical and lab characteristic of OCI as compared to axSpA in the rheumatology setting.

\begin{tabular}{|c|c|c|c|}
\hline \multirow[t]{2}{*}{ Characteristics } & & & \multirow[t]{2}{*}{ p-value } \\
\hline & $N=60$ & $N=120$ & \\
\hline Age, years & $40.3 \pm 10.0$ & $39.4 \pm 11.3$ & 0.51 \\
\hline Female sex, $\%$ & $96.7 \%$ & $41.7 \%$ & $<0.001$ \\
\hline Age at back pain onset, years & $29.7 \pm 9.0$ & $30.5 \pm 9.0$ & 0.59 \\
\hline Back pain duration, years & $9.0 \pm 7.9$ & $8.9 \pm 8.0$ & n.a. ${ }^{*}$ \\
\hline HLA-B27 positive, $\%$ & $35.2 \%$ & $84.2 \%$ & $<0.001$ \\
\hline CRP, mg/l & $2.1 \pm 2.1$ & $11.3 \pm 27.6$ & $<0.001$ \\
\hline Elevated CRP (>5mg/), \% & $7.1 \%$ & $41.3 \%$ & $<0.001$ \\
\hline Inflammatory back pain, \% & $39.5 \%$ & $92.3 \%$ & $<0.001$ \\
\hline Good response to NSAIDs, $\%$ & $73.8 \%$ & $76.9 \%$ & 0.67 \\
\hline Peripheral arthritis, $\%$ & $4.5 \%$ & $12.5 \%$ & 0.25 \\
\hline Enthesitis of the heel, \% & $4.8 \%$ & $15.8 \%$ & 0.11 \\
\hline Dactylitis, \% & $0 \%$ & $5.0 \%$ & 0.60 \\
\hline Uveitis, $\%$ & $0 \%$ & $11.7 \%$ & 0.011 \\
\hline Psoriasis, \% & $5.6 \%$ & $3.3 \%$ & 0.68 \\
\hline Inflammatory bowel disease, $\%$ & $1.8 \%$ & $2.5 \%$ & 1.00 \\
\hline Family history of SpA, \% & $32.7 \%$ & $20.8 \%$ & 0.12 \\
\hline BASDAI, NRS points (0-10) & $4.6 \pm 2.0$ & $4.0 \pm 2.0$ & 0.17 \\
\hline BASFI, NRS points (0-10) & $3.4 \pm 2.2$ & $3.1 \pm 2.3$ & 0.49 \\
\hline Menell's test positive, $\%$ & $37.5 \%$ & $62.5 \%$ & 0.09 \\
\hline Patrick's test positive, $\%$ & $45.8 \%$ & $69.6 \%$ & 0.07 \\
\hline Tenderness in the SIJ area, \% & $75.6 \%$ & $66.7 \%$ & 0.48 \\
\hline Schober's test, cm & $4.2 \pm 0.9$ & $4.6 \pm 2.1$ & 0.63 \\
\hline Lateral spinal flexion, $\mathrm{cm}$ & $15.6 \pm 5.0$ & $15.3 \pm 4.5$ & 0.83 \\
\hline
\end{tabular}

${ }^{\star}$ Matching variable

Results: The main characteristics of the two groups are presented in the table. Most importantly, all but 2 patients with $\mathrm{OCl}$ were females and had a significantly lower prevalence of inflammatory back pain, lower level of CRP stressing a rather non-inflammatory nature of this condition. All patients were referred because of possible axial SpA, therefore SpA features, although being lower than in axSpA patients (table 1), were higher than can normally expected in $\mathrm{OCI}$ patients. This is probably the reason why a statistical significance in comparison to axSpA was observed for uveitis only. There was no difference in age of back pain onset (but age $<45$ years was a referral parameter). Signs of sacroiliitis at physical examination were only slightly more frequent in axSpA; there were no differences in spinal mobility. The level of symptoms (BASDAI) and the perceived level of functional disability (BASFI) were comparable between groups. $83 \%$ of female patients with $\mathrm{OCI}$ reported a history of at least one pregnancy with a mean number of pregnancies of 3 (median=3, range $1-8$ ).

Conclusions: $\mathrm{OCI}$ manifesting with chronic back pain starting prior to 45 years of age represents an important differential diagnosis for axSpA. A constellation of a female sex (with a history of pregnancies), negative HLA-B27 and negative CRP seems to be of differential diagnostic value as compared to axSpA.

Disclosure of Interest: None declared

DOI: 10.1136/annrheumdis-2018-eular.4256

\section{FRI0192 PREDICTORS OF SEVERE HIP INVOLVEMENT IN ANKYLOSING SPONDYLITIS: DATA FROM NATIONAL INPATIENT SAMPLE}

P. Karmacharya ${ }^{1}$, D.R. Poudel ${ }^{2}$, P. Shrestha ${ }^{2}$, R. Dhital ${ }^{2}$, J.M. Davis III ${ }^{1}$.

${ }^{1}$ Rheumatology, Mayo clinic, Rochester, ${ }^{2}$ Reading Hospital and Medical Center, Reading, USA

Background: Hip involvement in ankylosing spondylitis (AS) is common (24\%$36 \%$ ), leading to worse functional outcomes. While some cases achieve long term remission, few develop progressive joint destruction with $5 \%-8 \%$ requiring hip replacement. Although studies in the past have looked at factors associated with severe hip involvement, these remain debated.

Objectives: To investigate the factors associated with severe hip disease in patients with AS using a large inpatient US database.

Methods: Using the Nationwide Inpatient Sample (NIS) data from 2009-2011, we identified patients with AS based on International Classification of Diseases, Ninth Revision (ICD-9) code 720.0 (first 5 positions) and identified patients with hip surgery with ICD-9 procedural codes $800.5,801.5,802.5,803.5,804.5,807.5$ $808.5,809.5,812.1,815.1,815.2,815.3$ (any position). NIS is the largest publicly available all-payer inpatient care database in the United States, sponsored by 
Agency for Healthcare Research and Quality as a part of Healthcare Cost and Utilisation Project. Univariate and multivariate binomial logistic regressions were used to derive odds ratio for predictors of hip surgery. Statistical analysis was done using STATA version 13.0 (College Station, TX).

Results: NIS database from 2009-2011 contained 3538 (weighted counts in the whole US population $n=17,480$ ) patients with AS. Out of those, 190 (weighted $\mathrm{n}=934)$ had hip surgery $(5.36 \%)$. Multivariate binomial regression analysis after controlling for confounders (table 1) showed male sex (OR 2.52, Cl 1.65-3.83, $\mathrm{p}<0.001$ ) and peripheral enthesopathy (OR 8.64, $\mathrm{Cl} 2.48-30.12, \mathrm{p}<0.001$ ) to be significantly associated with hip surgery in AS patients, and an inverse relationship with inflammatory bowel disease (IBD) (OR $0.35, \mathrm{Cl} 0.16-0.76, \mathrm{p}=0.01$ ) was seen.

\begin{tabular}{lccccc}
\hline AS with Hip Surgery & $\begin{array}{c}\text { Odds } \\
\text { Ratio }\end{array}$ & $\begin{array}{c}\text { Standard } \\
\text { error }\end{array}$ & $\begin{array}{c}p \text { - } \\
\text { value }\end{array}$ & \multicolumn{2}{c}{$95 \mathrm{Cl}$} \\
& & & & $\begin{array}{c}\text { Lower } \\
\text { limit }\end{array}$ & $\begin{array}{c}\text { Upper } \\
\text { limit }\end{array}$ \\
\hline Age & 1 & 0 & 0.46 & 0.99 & 1.01 \\
Male sex & $\mathbf{2 . 5 2}$ & $\mathbf{0 . 5 4}$ & $<0.001$ & $\mathbf{1 . 6 5}$ & $\mathbf{3 . 8 3}$ \\
Non-white & 1.11 & 0.25 & 0.65 & 0.71 & 1.74 \\
Income quartile & 1.33 & 0.21 & 0.07 & 0.97 & 1.83 \\
CAD & 0.6 & 0.16 & 0.06 & 0.35 & 1.02 \\
CKD & 0.65 & 0.31 & 0.36 & 0.25 & 1.66 \\
DM & 0.64 & 0.17 & 0.09 & 0.38 & 1.07 \\
CHF & 0.14 & 0.14 & 0.05 & 0.02 & 1.04 \\
Current smoking & 0.75 & 0.18 & 0.23 & 0.46 & 1.20 \\
Obesity & 1.24 & 0.35 & 0.46 & 0.71 & 2.16 \\
Uveitis & 1.04 & 0.77 & 0.96 & 0.25 & 4.43 \\
IBD & $\mathbf{0 . 3 5}$ & $\mathbf{0 . 1 4}$ & $\mathbf{0 . 0 1}$ & $\mathbf{0 . 1 6}$ & $\mathbf{0 . 7 6}$ \\
Psoriasis & 0.85 & 0.64 & 0.84 & 0.2 & 3.74 \\
Peripheral & $\mathbf{8 . 6 4}$ & $\mathbf{5 . 5}$ & $<0.001$ & $\mathbf{2 . 4 8}$ & $\mathbf{3 0 . 1 2}$ \\
enthesopathy & & & & & \\
Constant & 0.04 & 0.01 & $<0.001$ & 0.02 & 0.06 \\
\hline
\end{tabular}

Conclusions: Our study found male sex and patients with peripheral enthesopathy to have higher odds of severe hip disease requiring surgery among hospitalised AS patients and significantly lower odds with IBD. Previous studies showed an association with age at onset, delay in diagnosis, bilateral involvement, axial/ enthesial disease and severe sacroiliitis. Some of these associations could not be analysed in our study due to lack of individual level patient data. Interestingly, epidemiological factors like smoking and obesity which have been linked to severe disease in PsA, were not found to have any significant association. Routine clinical hip exam and radiological imaging might help to identify high-risk patients. Early therapeutic strategies might be indicated for this specific population to prevent severe hip disease and need for hip replacement surgery.

Disclosure of Interest: None declared

DOI: 10.1136/annrheumdis-2018-eular.5031

\section{FRI0193 PROGNOSTIC MARKERS IN AXIAL SPONDYLOARTHRITIS (PROMISE) - CROSS SECTIONAL EVALUATION OF SERUM BIOMARKERS IN AXSPA, MECHANICAL BACK PAIN AND HEALTHY CONTROLS}

E. Reilly ${ }^{1}$, C. Fisher ${ }^{2}$, R. Sengupta ${ }^{1} .{ }^{1}$ Royal National Hospital for Rheumatic Diseases, Bath; ${ }^{2}$ University College London, London, UK

Background: In recent years there has been increasing interest in biomarkers in axial spondyloarthritis, for diagnosis, disease prognostication, and to monitor treatment effect. $^{12}$ Many biomarkers have been evaluated, but the role each of these plays and how they may interact is unclear.

Objectives: Our aim was to evaluate a broad panel of serum biomarkers in a large mixed cohort of patients, with Ankylosing Spondylitis (AS), non radiographic axial Spondyloarthritis (nr-axSpA), mechanical back pain (MBP) and healthy controls $(\mathrm{HC})$, in order to identify any potential biomarkers for diagnosis by assessing the differences between the groups.

Methods: Cross sectional evaluation of 46 serum biomarkers was undertaken by Myriad RBM using multiplexed immunoassays of Multi-Analyte Panels, in a cohort of patients from a tertiary referral centre, consented as part of the Bath Spondyloarthritis BioBank. Validated patient reported outcomes (including BASDAI, $\mathrm{BASFI}$ ) and BASMI were completed. $50 \mathrm{HC}$ blood samples were also collected at University College London for biomarker analysis.

Results: 331 patients were included in the study, of which $59.5 \%$ AS, $8.2 \% \mathrm{nr}-$ axSpA, $15.7 \%$ mechanical back pain, $15.1 \%$ HC. $64.7 \%$ were male, mean age 44.2 years (SD 16.6), mean disease duration in the AS group of 22.4 years (SD 13.6) with $84 \%$ HLA B27 positive.
IL1 alpha and beta, IL1 receptor antagonist, IL2, 3, 4, 5, 7, 10, 15, 17, IL12 subunit p70, factor VII, GMCSF, IFN gamma, MMP9, TNF beta were the only biomarkers not to show statistical differences across the diagnostic groups (table 1.). 12 biomarkers showed a statistical difference between genders (table 1, column 1, p value significance indicated with ${ }^{*}<0.05,{ }^{* *}<0.01$ using Mann Whitney $U$, in addition to Factor VII*).

Abstract FRI0193 - Table 1. Statistically significant serum biomarker results by diagnosis

\begin{tabular}{|c|c|c|c|c|c|}
\hline $\operatorname{Mean}(\mathrm{SO})$ & AS & $n r-2 k S_{Q A}$ & $\begin{array}{l}\text { Mechanical } \\
\text { backpain }\end{array}$ & $\begin{array}{l}\text { He althy } \\
\text { controls }\end{array}$ & $\begin{array}{l}\text { P value using } \\
\text { Kruskal Wallis }\end{array}$ \\
\hline $\mathrm{N}$ & 197 & 27 & 52 & 50 & \\
\hline Alpha 1 agti tryosio mg/ml & $3.2(1.2)$ & $2.3(0.8)$ & $2.1(0.8)$ & $1.4(0.4)$ & $<0.001$ \\
\hline Alpha 2 macroglobulin, $\mathrm{mg} / \mathrm{ml}$ & $4.0(1.4)$ & $3.7(1.2)$ & $3.6(1.5)$ & $3.1(1.9)$ & $<0.001$ \\
\hline *eta 2 macroglobulin, yl/ml & $3.4(2.7)$ & $2.2(0.8)$ & $2.0[0.9)$ & $1.6(0.3)$ & $<0.001$ \\
\hline $\begin{array}{l}\text { Brain derived Neucotcoplaic Factor, } \\
\mathrm{ng} / \mathrm{ml}\end{array}$ & $28.4(8.3)$ & $\frac{1.2(0.07}{30.3(8.2)}$ & $\frac{2.0(3.9)}{28.9(7.2)}$ & $21.0(4.5)$ & $<0.001$ \\
\hline CReactive Protein, y $\mathrm{g} / \mathrm{ml}$ & $29.6(69.1)$ & $4.6(9.2)$ & $4.7(9.0)$ & $3.0(4.4)$ & $<0.001$ \\
\hline Complement $\mathrm{C} 3, \mathrm{mg} / \mathrm{ml}$ & $2.8(1.3)$ & $1.9(0.9)$ & $1.8(1.0)$ & $0.8(0.2)$ & $<0.001$ \\
\hline " Eetaxia $1, \mathrm{DE} / \mathrm{ml}$ & $374.1(193.5)$ & $\begin{array}{l}241.4 \\
(174.8) \\
\end{array}$ & $\begin{array}{l}241.4 \\
(161.2)\end{array}$ & $170.1(1235)$ & $<0.001$ \\
\hline "Ferritin, ng/ml & $248.5(231.2)$ & $\begin{array}{l}177.9 \\
(177.3)\end{array}$ & $\begin{array}{l}\frac{(01.2)}{205.4} \\
(212.0)\end{array}$ & $89.9(74.9)$ & $<0.001$ \\
\hline "Fibrinogen, mg/ml & $0.0(0.0)$ & $0.0(0.0)$ & 0.0 & $0.0(0.0)$ & $<0.001$ \\
\hline Heotoglobin, mg/ml & $4.0(4.2)$ & $2.5(1.4)$ & $1.6(1.3)$ & $1.6(0.8)$ & $<0.001$ \\
\hline $\begin{array}{l}\text { Inte rcellular Adhesion Molecule 1, } \\
\mathrm{ng} / \mathrm{ml}\end{array}$ & $175.2(81.5)$ & $149.6(61.4)$ & $154.5(84.2)$ & $98.8(22.3)$ & $<0.001$ \\
\hline $\mathrm{ILG}, \mathrm{gg} / \mathrm{ml}$ & $2.4(6.9)$ & $0.3(1.4)$ & $0.7(1.6)$ & & $<0.001$ \\
\hline $118,0 \mathbb{R} / \mathrm{ml}$ & $33.4(69.6)$ & $\begin{array}{l}329.7 \\
(1484.9)\end{array}$ & $52.7(127.0)$ & $4.4(7.1)$ & $<0.001$ \\
\hline IL12 subunit $40, \mathrm{ng} / \mathrm{ml}$ & $0.4(0.2)$ & $0.4(0.2)$ & $0.3(0.3)$ & $0.3(0.2)$ & 0.001 \\
\hline 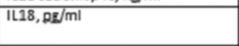 & $321.8(157.6)$ & $\begin{array}{l}295.1 \\
(171.5)\end{array}$ & $\begin{array}{l}281.8 \\
(204.3)\end{array}$ & $146.2(60.8)$ & 80.001 \\
\hline$\cdot|L 23, n g / m|$ & $0.8(1.0)$ & $0.3(0.7)$ & $0.3(0.7)$ & $0.1(0.4)$ & 80.001 \\
\hline $\begin{array}{l}\text { Macrophage Inflammatory Protain } \\
1 \mathrm{alpha}, \mathrm{gg} / \mathrm{ml}\end{array}$ & $23.1(62.1)$ & $20.2(41.2)$ & $24.2(37.6)$ & 0.0 & 0.005 \\
\hline $\begin{array}{l}\text { Macrophage Inflammatory Protein } \\
1 \text { beta, } \mathrm{pg} / \mathrm{ml}\end{array}$ & $678.5(595.4)$ & $\begin{array}{l}604.0 \\
(382.2)\end{array}$ & $\begin{array}{l}618.3 \\
(447.8)\end{array}$ & $290.8(192.3)$ & $<0.001$ \\
\hline $\begin{array}{l}\text { Matrix Metalloproteinase 3, } \\
\mathrm{ng} / \mathrm{ml}\end{array}$ & $24.2(15.9)$ & $11.6(4.6)$ & $14.1(8.3)$ & $13.5(6.7)$ & $<0.001$ \\
\hline 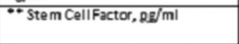 & $550.1(222.6)$ & $\begin{array}{l}362.6 \\
(259.0)\end{array}$ & $\begin{array}{l}389.1 \\
(235.5)\end{array}$ & $173.2(164.9)$ & $<0.001$ \\
\hline $\begin{array}{l}\text { Teell Specific Prote in RANTES, } \\
\mathrm{ng} / \mathrm{ml}\end{array}$ & $26.5(15.1)$ & $\frac{25.0(16.8)}{25.0(1)}$ & $21.2(10.5)$ & $20.4(7.6)$ & 0.03 \\
\hline $\begin{array}{l}\text { "Tissue Inhibitor of } \\
\text { Metallepcoteinases } 1, \mathrm{ng} / \mathrm{ml}\end{array}$ & $262.1(94.4)$ & $197.9(55.8)$ & $186.7(44.9)$ & $141.7(32.0)$ & $<0.001$ \\
\hline TNF alpha, pr/ml & $13.3(30.2)$ & $8.9(30.3)$ & $0.6(4.3)$ & 0.0 & $<0.001$ \\
\hline TNF receptor 2,ng/ml & $298.2(740.4)$ & $92.9(433.1)$ & $9.7(5.2)$ & $5.8(1.8)$ & 80.001 \\
\hline $\begin{array}{l}\text { - Vascular Cell Adhesion Molecule } \\
1, \mathrm{ng} / \mathrm{ml}\end{array}$ & $\begin{array}{l}1093.0 \\
(465.3)\end{array}$ & $\begin{array}{l}931.6 \\
(307.9)\end{array}$ & $\begin{array}{l}965.9 \\
(391.9)\end{array}$ & $651.0(141.1)$ & $<0.001$ \\
\hline $\begin{array}{l}\text { Vascular Endothelial Growh } \\
\text { Factor, ag/ml }\end{array}$ & $493.8(359.1)$ & $\begin{array}{l}439.6 \\
(316.8)\end{array}$ & $\begin{array}{l}394.1 \\
(215.4)\end{array}$ & $261.7(168.6)$ & $<0.001$ \\
\hline Vitamin D Binding Protein, $y \mathrm{~g} / \mathrm{ml}$ & $538.1(233.7)$ & \begin{tabular}{|l|}
414.6 \\
$(186.6)$ \\
\end{tabular} & $\begin{array}{l}439.3 \\
(227.9)\end{array}$ & $334.4(135.1)$ & $<0.001$ \\
\hline Von Willebrand Factor, yg/n & $161.2(89.9)$ & $110.6(51.9)$ & $109.2(77.6)$ & $95.5(51.1)$ & 80.001 \\
\hline $\begin{array}{l}\text { Monocyte Chemotactic Protein 1, } \\
\mathrm{gg} / \mathrm{ml}\end{array}$ & $484.7(220.0)$ & $\begin{array}{l}524.9 \\
(369.2)\end{array}$ & $\begin{array}{l}396.5 \\
(174.9)\end{array}$ & $314.7(133.6)$ & $<0.001$ \\
\hline
\end{tabular}

Conclusions: Serum biomarkers have been shown to vary with gender and diagnosis. Further work is planned to evaluate their relationship to disease activity using outcome measures such as the BASDAI, and radiographic scoring, to bette understand the role of each factor and combination of factors, and any causal link.

\section{REFERENCES}

[1] Maksymowych WP. An update on biomarker discovery and use in axia spondyloarthritis. Expert Rev Mol Diagn [Internet]. 2017 Nov;217(11):96574. [cited 2017 Dec 7]. Available from: https://www.tandfonline.com/doi/full/ 10.1080/14737159.2017.1381562

[2] Reveille JD. Biomarkers for diagnosis, monitoring of progression, and treatment responses in ankylosing spondylitis and axial spondyloarthritis. Clin Rheumatol [Internet] 2015 Jun 5;34(6):1009-18. [cited 2017 Jul 10]. Available from: http://link.springer.com/10.1007/s10067-015-2949-3

Acknowledgements: This study was undertaken as part of an ongoing piece of work that is being funded by Celgene.

Disclosure of Interest: None declared

DOI: 10.1136/annrheumdis-2018-eular.6740

\section{FRI0194 ANKYLOSING SPONDYLITIS DISEASE ACTIVITY SCORE (ASDAS) BASED ON A QUICK QUANTITATIVE CRP ASSAY PERFORMS SIMILARLY WELL TO ASDAS BASED ON CONVENTIONAL CRP IN PATIENTS WITH AXIAL SPONDYLOARTHRITIS}

F. Proft ${ }^{1}$, B. Muche ${ }^{1}$, M. Schmidt ${ }^{1}$, L. Spiller ${ }^{1}$, V. Rios Rodriguez ${ }^{1}$, J. Rademacher ${ }^{1}$, A.-K. Weber ${ }^{1}$, S. Lüders ${ }^{1}$, M. Protopopov ${ }^{1}$, I. Spiller ${ }^{1}$, J. Sieper ${ }^{1}$, D. Poddubnyy ${ }^{1,2}$. ${ }^{1}$ Charité - Universitätsmedizin Berlin; ${ }^{2}$ German Rheumatism Research Centre, Berlin, Germany

Background: The Ankylosing Spondylitis Disease Activity Score (ASDAS) is a composite index to assess disease activity in patients with axial spondyloarthritis (axSpA). According to the treat-to-target (T2T) recommendations for SpA, and the 